\title{
The Isolation of Conditional Ineffective Mutants of Rhizobium leguminosarum
}

\author{
By J. E. BERINGER, A. W. B. JOHNSTON AND B. WELLS \\ John Innes Institute, Colney Lane, Norwich $\mathrm{NR}_{4}{ }_{7} \mathrm{UH}$
}

(Received 26 July 1976; revised 2 September 1976)

\section{SUMMAR Y}

Ineffective mutants of Rhizobium leguminosarum were isolated at a frequency of about $3 \%$ following mutagenesis of an effective parental strain. Two mutants were temperature sensitive; they were ineffective at $26^{\circ} \mathrm{C}$ but were effective at $13{ }^{\circ} \mathrm{C}$. The morphologies of the nodules formed by these two mutants at $26^{\circ} \mathrm{C}$ were different from each other and from normal nodules. Temperature-shift experiments using nodulated plants also indicated that the mutants had different properties.

\section{INTRODUCTION}

Genetic studies of the interactions between Rhizobium species and leguminous plants aimed at elucidating the role of each member of the partnership in the formation of nitrogenfixing root nodules have been hampered by a dearth of symbiotically defective plant or bacterial mutants. No techniques exist for readily isolating plant mutants though it should be possible to isolate bacterial mutants. Strains that are unable to fix nitrogen (ineffective) can be isolated from nodules in the field, but few have been maintained in culture collections and they are likely to be of limited value for genetic studies because they cannot be compared with effective parental strains.

Symbiotically defective mutants have been isolated indirectly: some auxotrophs (Schwinghamer, 1969; Dénarié, Truchet \& Bergeron, 1976) and some mutants resistant to bacteriophages (Kleczkowska, I950), antimetabolites (Schwinghamer, I968) and antibiotics (Schwinghamer, 1964; MacKenzie \& Jordan, 1970) are either non-infective or ineffective. However, such mutants are likely to be pleiotropic and the symbiotic defect may be a trivial consequence of the selected phenotype. Also, all those classes of symbiotically defective mutants which do not give such phenotypes will not be isolated.

To overcome these limitations we have looked directly for symbiotically defective mutants among the survivors of an $N$-methyl- $N^{\prime}$-nitro- $N$-nitrosoguanidine (NTG) mutagenesis (Beringer, 1974) of an effective strain. This paper describes the properties of two such mutants of Rhizobium leguminosarum.

\section{METHODS}

Bacterial strain. Rhizobium leguminosarum strain 603 is a phenylalanine-requiring derivative of strain 300 (Johnston \& Beringer, 1975). It forms effective nodules on peas.

Growth media. The media used for the culture of $R$. leguminosarum and the nitrogen-free salts media for the growth of peas have been described (Beringer, 1974).

Nodulation test. Peas, (Pisum sativum) var. Wisconsin Perfection, were inoculated and 
grown as described by Beringer (I974) except that they were grown in growth cabinets with a $20 \mathrm{~h}$ day-length.

Mutagenesis and isolation of ineffective mutants. Strain 603 was mutagenized with NTG as described by Beringer (1974). The mutagenesis was very effective, inducing about $5 \%$ auxotrophs. Survivors not carrying auxotrophic mutations (except phenylalanine) were tested individually for their symbiotic properties on peas growing at $26 \pm 2{ }^{\circ} \mathrm{C}$. (This temperature was chosen because it is the highest at which effective nodules formed on Wisconsin Perfection peas under our conditions and it allowed the potential for the isolation of temperature-sensitive mutants.) Plants were examined for nodule formation after 4 to 5 weeks and the whole root systems were assayed for acetylene reduction at the temperature at which the plants were growing as a measure of nitrogenase activity (Johnston \& Beringer, 1975). Strains giving rates of acetylene reduction of less than $5 \%$ of those of control plants inoculated with effective $R$. leguminosarum were re-tested on four more plants; two were grown at $26 \pm 2{ }^{\circ} \mathrm{C}$ and two at $13 \pm 2{ }^{\circ} \mathrm{C}$.

Electron microscopy of nodules. Nodules were prepared for electron microscopy by cutting them into slices and placing them in a solution of $2.5 \%(\mathrm{v} / \mathrm{v})$ glutaraldehyde in $60 \mathrm{~mm}-$ phosphate buffer containing $0.3 \%$ (w/v) sucrose and $0.14 \%(\mathrm{w} / \mathrm{v}) \mathrm{CaCl}_{2} \cdot 2 \mathrm{H}_{2} \mathrm{O}$ (phosphate/ sucrose buffer, $\mathrm{pH} 7 \cdot 6$ ). Tubes containing the fixed sample were placed in a vacuum for 5 to Io min to remove trapped air. The fixative was then replaced and the tissue was incubated overnight at $4{ }^{\circ} \mathrm{C}$. After washing with phosphate/sucrose buffer the tissue was post-fixed in $2 \%(\mathrm{w} / \mathrm{v})$ osmic acid in phosphate/sucrose buffer for $\mathrm{I} h$ at room temperature. The fixed tissue was then washed with phosphate/sucrose buffer and dehydrated with an ethanol/water series. During the dehydration the tissue was stained with a saturated solution of uranyl acetate in $70 \%(\mathrm{v} / \mathrm{v})$ alcohol. After dehydration the tissue was embedded in Spurr's (1969) firm resin.

Sections, 50 to $75 \mathrm{~nm}$ thick, were cut using a Cambridge Huxley ultramicrotome and stained with lead acetate (Millonig, 196I). The sections were examined with a Siemens Elmiskop IA electron microscope.

\section{RESULTS AND DISCUSSION}

Of 196 survivors of the mutagenesis, three were ineffective at $26^{\circ} \mathrm{C}$ but not at $13{ }^{\circ} \mathrm{C}$ while three more were ineffective at both temperatures (i.e. reduced acetylene at less than I $\%$ of the rate of controls). Two strains showing the temperature-sensitive response (7106 and 7 I 55) were studied further in a series of temperature-shift experiments, two plants being sacrificed and assayed for acetylene reduction at each sample time.

Plants inoculated with strain 7155 , grown at $13{ }^{\circ} \mathrm{C}$ until acetylene-reducing activity was detected and then transferred to $26^{\circ} \mathrm{C}$, were not able to reduce acetylene after 3 days at $26^{\circ} \mathrm{C}$, corresponding with a change in nodule colour from pink to green. Plants moved back to $\mathrm{I} 3{ }^{\circ} \mathrm{C}$ after only I or 2 days at $26^{\circ} \mathrm{C}$ and assayed 3 days later, could still reduce acetylene at rates comparable to plants maintained at this temperature, indicating a requirement of 48 to $72 \mathrm{~h}$ to inactivate the acetylene-reducing ability of the nodules. In plants kept at $26^{\circ} \mathrm{C}$ for 5 days before transfer back to $13{ }^{\circ} \mathrm{C}$, it was 6 to $\mathrm{I} 5$ days before acetylene reduction was detectable. Resumption of acetylene reduction after 6 days appeared to be due to changes in existing nodules because pink tips appeared on them at this time, while those plants requiring longer than 6 days produced new effective nodules. This difference was probably related to the degree of maturity of the nodules on transfer from 13 to $26{ }^{\circ} \mathrm{C}$; small nodules could grow when transferred back to $13{ }^{\circ} \mathrm{C}$, while plants with normal sized nodules had to 


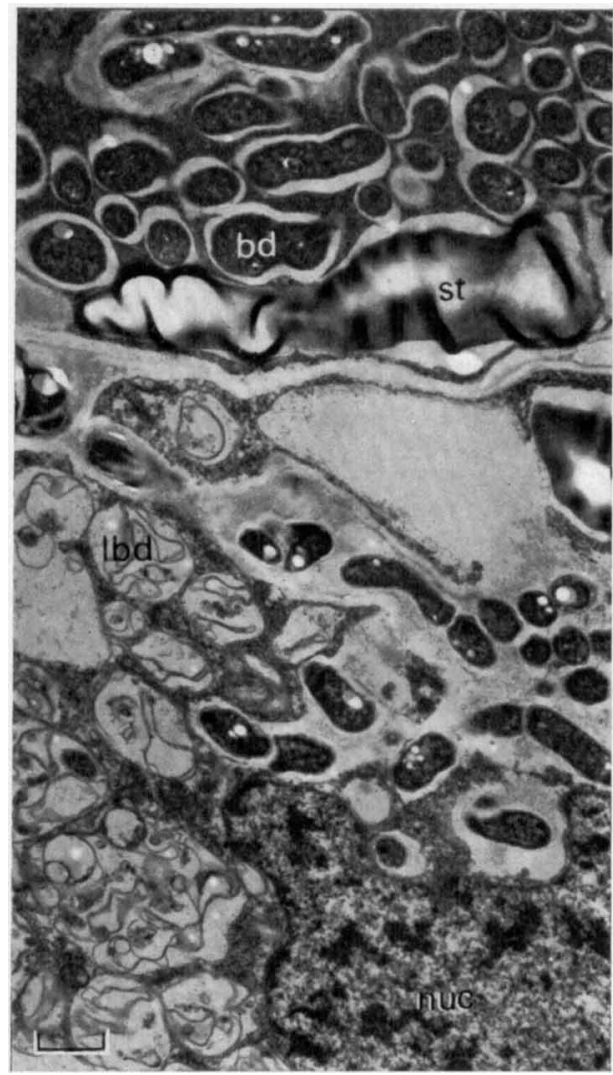

Fig. I

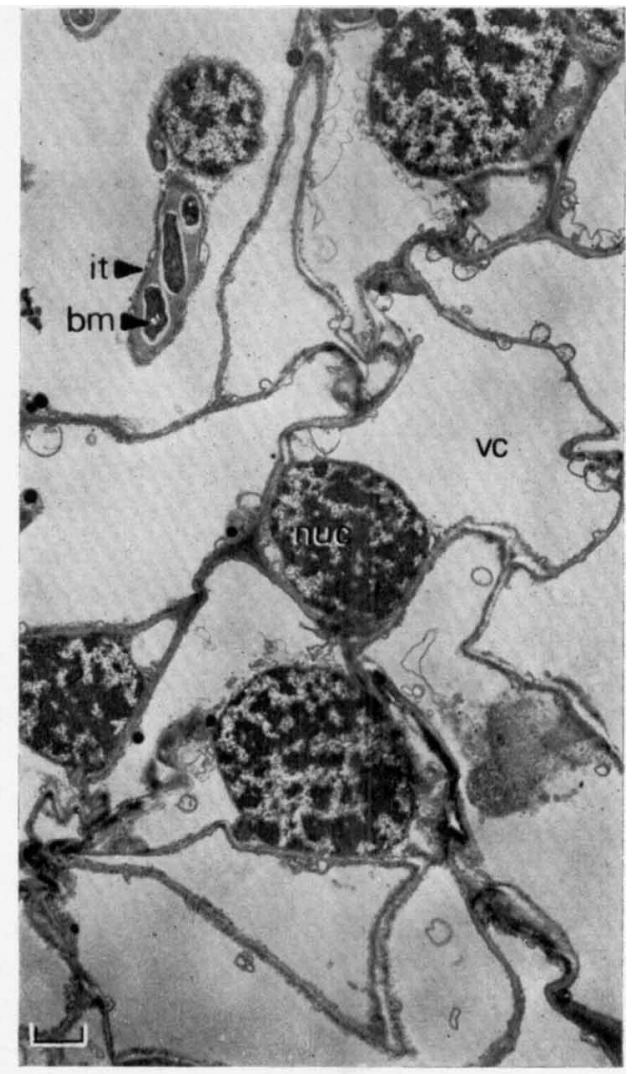

Fig. 2

Fig. I. Thin section of a nodule produced by strain 7r 55 at $26^{\circ} \mathrm{C}$ stained with lead acetate, showing bacteroids (bd) and lysed bacteroids (lbd). Deposits of starch (st) and a plant cell nucleus (nuc) are also visible. Bar marker represents I $\mu \mathrm{m}$.

Fig. 2. Thin section of a nodule produced by strain 7106 at $26^{\circ} \mathrm{C}$ stained with lead acetate showing bacteria (bm) contained in an infection thread (it). Note the absence of bacteroids and the presence of large vacuolated cells (vc). Spherical plant cell nuclei (nuc) are visible. Bar marker represents I $\mu \mathrm{m}$.

produce new ones. The size difference was not correlated with the length of time at $26^{\circ} \mathrm{C}$ required before plants ceased to be able to reduce acetylene.

Plants inoculated with strain 7106 , and grown at $13{ }^{\circ} \mathrm{C}$ until acetylene-reducing activity was detectable, continued to reduce acetylene for $\mathrm{I} 6$ to $2 \mathrm{I}$ days after transfer to $26^{\circ} \mathrm{C}$; there was a gradual decrease in the level of acetylene reduction over this period and a slow conversion of the nodules from pink to green. It was possible that the acetylene-reducing ability of plants nodulated with strain 7106 was inhibited in a comparatively short time at $26^{\circ} \mathrm{C}$ but that the effect of this pulse at the higher temperature was not detectable until some time later. To test this, plants were transferred from 13 to $26^{\circ} \mathrm{C}$ and maintained at $26{ }^{\circ} \mathrm{C}$ for 12 days. They were still able to reduce acetylene after this time and when they were moved back to $13{ }^{\circ} \mathrm{C}$ and grown for a further I I days at this temperature, normal levels of acetylenereducing activity were found. This indicates that the inhibition of acetylene-reducing activity was insensitive to exposure to $26^{\circ} \mathrm{C}$ for as long as $\mathrm{I} 2$ days.

Plants were inoculated with strain 7106 and grown at $13{ }^{\circ} \mathrm{C}$ until effective nodules had formed. They were then transferred to $26^{\circ} \mathrm{C}$ for 16 days after which time no acetylene- 
reducing activity was detectable. There was no resumption of activity when these plants were returned to $13{ }^{\circ} \mathrm{C}$ for $\mathrm{I} 2$ days, indicating that the defect in strain 7106 was not immediately reversible on transfer to the permissive temperature. Plants which were grown at $26^{\circ} \mathrm{C}$ from the time of inoculation and then transferred to $13{ }^{\circ} \mathrm{C}$ at the time when normalsized nodules had formed, required about 15 days at the permissive temperature before acetylene-reducing activity was detectable, as did plants inoculated with strain 7155 .

Control plants inoculated with strain 603 at $13{ }^{\circ} \mathrm{C}$ were used to determine whether the transfer from 13 to $26^{\circ} \mathrm{C}$ so disturbed the normal nodule that its acetylene-reducing ability was damaged. Plants transferred to $26^{\circ} \mathrm{C}$ continued to reduce acetylene at a comparable rate to similar plants at $13{ }^{\circ} \mathrm{C}$; after 14 days at $26^{\circ} \mathrm{C}$ no obvious decline in acetylene-reducing ability or greening of the nodules was apparent.

Mature nodules from plants inoculated with the mutants and also with wild-type strains at 13 and $26^{\circ} \mathrm{C}$ were sectioned and examined in an electron microscope. Nodules formed by wild-type strains at 13 or $26^{\circ} \mathrm{C}$ were indistinguishable. Nodules produced by strain 7155 at $\mathrm{I} 3$ or $26^{\circ} \mathrm{C}$ were similar to wild-type nodules, though at both temperatures fewer plant cells contained bacteroids. There were many vacuolated plant cells at both temperatures and at $26^{\circ} \mathrm{C}$ many of the bacteroids appeared to be partially lysed (Fig. I). At $13{ }^{\circ} \mathrm{C}$ nodules formed by strain 7106 were similar in morphology to those of the wild type, while at $26^{\circ} \mathrm{C}$ there appeared to be no release of bacteria from infection threads, and no bacteroids were detectable (Fig. 2). The plant cells in these nodules were abnormally small and highly vacuolated.

These observations of nodule structure are consistent with the data from the temperatureshift experiments. It would be expected that strain 7106 would continue to be able to reduce acetylene for many days since there would be no reason to assume that pre-existing bacteroids and liberated bacteria could not undergo a normal symbiosis. As plants inoculated with strain 7106 could no longer reduce acetylene after transfer to $26^{\circ} \mathrm{C}$, successive rounds of re-infection of plant cells may be required for continued nodule function.

The relatively high frequency of ineffective mutants found after NTG mutagenesis might indicate that many bacterial genes determine the steps leading to nitrogen fixation and that fewer would be involved in recognition and penetration since no non-infective mutants were found. This may be misleading because of the small sample and because small numbers of infective revertants in the non-infective inoculum may form nodules. Reconstruction experiments (Johnston, unpublished observations) have shown that fewer than Io wild-type $R$. leguminosarum in the presence of more than $10^{8}$ of a non-infective strain were able to nodulate peas. Therefore, a non-infective mutant with a reversion rate greater than $10^{-8}$ might not be detected.

The symbiotically defective mutants discussed here are unlikely to have arisen spontaneously because the spontaneous loss of effectiveness in our $R$. leguminosarum isolates has not been observed (frequency less than $0.5 \%$ ). These results indicate that, as expected, symbiotically defective mutants of Rhizobium can be obtained after mutagenesis. Furthermore, in $R$. leguminosarum the frequency of occurrence of such mutants was similar to that for auxotrophic mutants and it was possible to obtain conditional mutants.

We thank Shelagh A. Hoggan and Audrey Plaskit for skilled technical assistance, Rogers Brothers Seed Company, Idaho Falls, Idaho, U.S.A., for a gift of Wisconsin Perfection seed, and Professor D. A. Hopwood for constructive criticism of the manuscript. 


\section{REFERENCES}

BERINGER, J. E. (1974). R factor transfer in Rhizobium leguminosarum. Journal of General Microbiology 84, I 88-198.

Dénarié, J., TruChet, G. \& Bergeron, B. (I976). Effects of some mutations on symbiotic properties of Rhizobium. In Symbiotic Nitrogen Fixation in Plants, International Biological Programme, vol. 7, pp. 47-6I. Edited by P. S. Nutman. Cambridge: Cambridge University Press.

Johnston, A. W. B. \& BERINGER, J. E. (1975). Identification of Rhizobium strains in pea root nodules using genetic markers. Journal of General Microbiology 87, 343-350.

KLECZKowSKA, J. (1950). A study of phage-resistant mutants of Rhizobium trifolii. Journal of General Microbiology 4, 298-310.

MACKENZIE, C. R. \& JoRDAN, D. C. (1970). Cell wall phospholipid and viomycin resistance in Rhizobium meliloti. Biochemical and Biophysical Research Communications 40, 1008-101 2.

Millonig, G. (1961). A modified procedure for lead staining of thin sections. Journal of Biophysical and Biochemical Cytology 1r, 736-748.

SCHwinghamer, E. A. (1964). Association between antibiotic resistance and ineffectiveness in mutant strains of Rhizobium spp. Canadian Journal of Microbiology ro, $22 \mathrm{I}-233$.

Schwinghamer, E. A. (1968). Loss of effectiveness and infectivity in mutants of Rhizobium resistant to metabolic inhibitors. Canadian Journal of Microbiology r4, 355-367.

SCHWINGHAMER, E. A. (1969). Mutation to auxotrophy and prototrophy as related to symbiotic effectiveness in $R$. leguminosarum and R. trifolii. Canadian Journal of Microbiology $15,61 \mathrm{I}-622$.

SpURR, A. R. (1969). A low-viscosity epoxy resin embedding medium for electron microscopy. Journal of Ultrastructure Research 26, 3I-43. 